\title{
Nonomuraea indica sp. nov., novel actinomycetes isolated from lime-stone open pit mine, India
}

\author{
Syed Raziuddin Quadri ${ }^{1,2,3}$, Xin-Peng Tian ${ }^{4}$, Jing Zhang ${ }^{4}$, Jie $\mathrm{Li}^{4}$, Guo-Xing Nie ${ }^{5}$, Shu-Kun Tang ${ }^{2}$, \\ Jamal Al Ruwaili ${ }^{1}$, Dayanand Agsar ${ }^{3}$, Wen-Jun $\mathrm{Li}^{2}$ and Syed G Dastager ${ }^{6}$
}

A Gram-positive, aerobic, nonmotile actinomycete strain designated DRQ-2 ${ }^{\top}$ was isolated from the soil sample collected from limestone open pit mine from the Gulbarga region, Karnataka province, India. Strain DRQ-2 ${ }^{\top}$ was identified as a member of the genus Nonomuraea by a polyphasic approach. Strain DRQ-2 ${ }^{\top}$ could be differentiated from other members of the genus Nonomuraea on the basis of physiology and 16S rRNA gene sequence analysis. The 16S rRNA gene sequence similarity of strain DRQ-2 ${ }^{\top}$ showed highest sequence similarity to Nonomuraea muscovyensis DSM $45913^{\top}(99.1 \%), N$. salmonea DSM $43678^{\top}(98.2 \%)$ and N. maheshkhaliensis JCM $13929^{\top}$ with $98.0 \%$, respectively. Chemotaxonomic properties showing predominant menaquinones of MK-9 $\left(\mathrm{H}_{4}\right)$, MK-9 $\left(\mathrm{H}_{2}\right)$ and MK-9 $\left(\mathrm{H}_{6}\right)$, major polar lipids comprised diphosphatidylglycerol, phosphatidylmono methyl ethanolamine (PME), phosphatidylethanolamine (PE), hydroxy-PME (OH-PME), hydroxy PE (OH-PEE), phosphatidylglycerol (PG), ninhydrin-positive phosphoglycolipid and unknown phospholipid, fatty acids with major amounts of $\mathrm{i}-\mathrm{C}_{16: 0}$, ai- $\mathrm{C}_{15: 0}$ and ai- $\mathrm{C}_{17: 0}$ supported allocation of the strain to the genus Nonomuraea. Results of DNA-DNA hybridization and physiological tests allowed genotypic and phenotypic differentiation of strain DRQ-2 ${ }^{\top}$ from closely related species. The genomic DNA G+C content of the organism was $72.5 \mathrm{~mol} \%$. On the basis of phenotypic, chemotypic and molecular characteristics, strain DRQ-2 ${ }^{\top}$ represents a novel species of the genus Nonomuraea, for which the name $N$. indica sp. nov. is proposed, with type strain DRQ-2 ${ }^{\top}$ ( = NCIM $5480^{\top}=$ CCTCC AA $209050^{\top}$ ). The Journal of Antibiotics (2015) 68, 491-495; doi:10.1038/ja.2015.24; published online 18 March 2015

\section{INTRODUCTION}

The genus Nonomuraea was initially proposed in 1988 by Goodfellow, Stackebrandt and Kroppenstedt, but the name was not formally recognized in bacterial taxonomy. Zhang et al. ${ }^{1}$ realized that the Microtetraspora pusilla group was phylogenetically distinct from other members of the genus Microtetraspora and established a new genus Nonomuraea to accommodate these species. Chiba et al. ${ }^{2}$ subsequently corrected the spelling to Nonomuraea. The genus was grouped within the family Streptosporangiaceae by Quintana et al. ${ }^{3}$ Currently this genus harbors 36 validly described species and subspecies; including recently described valid members, like $N$. fuscirosea, N. jabiensis, N. thailandensis and N. soli. ${ }^{4-7}$ Members of this genus are believed to be widely distributed in soils, but are considered to be under speciated. ${ }^{3}$ Nonomuraea species can be separated from one another using a combination of phenotypic properties. ${ }^{2,8,9}$ The aim of the present study was to establish the taxonomic position of a lime-stone open pit strain DRQ-2 ${ }^{\mathrm{T}}$ within its classification in the genus Nonomuraea.

\section{MATERIALS AND METHODS}

Strain and culture collection

The soils of lime-stone open pit mine from the Gulbarga region, Karnataka province, India seems to be gold mine for the rich biodiversity of actinobacteria. Streptomyces gulbargensis, S. tritolerans and S. deccanensis ${ }^{10-12}$ have already been reported as novel isolates from these soils. The strain DRQ-2 ${ }^{\mathrm{T}}$ was isolated by standard serial dilution technique from the soil collected from lime-stone open pit mines. Aliquots of serial dilutions were spread onto starch-casein agar ( $1 \%$ soluble starch, $0.03 \%$ casein, $0.2 \% \mathrm{KNO}_{3}$, $0.2 \% \mathrm{NaCl}, 0.2 \% \mathrm{KH}_{2} \mathrm{PO}_{4}, 0.002 \% \mathrm{CaCO}_{3}, 0.005 \% \mathrm{MgSO}_{4} \cdot 7 \mathrm{H}_{2} \mathrm{O}, 0.001 \%$ $\mathrm{FeSO}_{4} \cdot 7 \mathrm{H}_{2} \mathrm{O}$ and $1.8 \%$ agar; $\mathrm{pH} 7.2$ ) and the plates were incubated at $45^{\circ} \mathrm{C}$ for 2 weeks. A single colony was selected and further streaked on International Streptomyces Project (ISP) medium 2 as proposed by Shirling and Gottlieb, ${ }^{13}$ at least three times. Strain DRQ-2 ${ }^{\mathrm{T}}$ was grown on ISP medium 3 for 14 days at $45^{\circ} \mathrm{C}$ for phenotypic and genetic comparison.

Morphological, physiological and biochemical characterization Strain DRQ-2 ${ }^{\mathrm{T}}$ grew well on ISP2, 3, 4, 5 and 6 media, nutrient Agar, Czapex dox agar, glucose-asparagine agar and starch casein agar. The aerial mycelia

\footnotetext{
${ }^{1}$ Department of Medical Laboratory Technology, Faculty of Applied Medical Sciences, Northern Border University, Arar, Northern Borders, Kingdom of Saudi Arabia; ${ }^{2}$ Key Laboratory of Microbial Diversity in Southwest China, Ministry of Education and Laboratory for Conservation and Utilization of Bio-resources, Yunnan Institute of Microbiology, Yunnan University, Kunming, Yunnan, PR China; ${ }^{3}$ Department of Microbiology, Gulbarga University, Gulbarga, Karnataka, India; ${ }^{4}$ Key Laboratory of Marine Bio-resources Sustainable Utilization CAS, RNAM Center for Marine Microbiology, Guangdong Key Laboratory of Marine Materia Medica, South China Sea Institute of Oceanology, Chinese Academy of Sciences, Guangzhou, PR China; ${ }^{5}$ College of Life Sciences, Henan Normal University, Xinxiang, PR China and ${ }^{6}$ NCIM-Resource Center, CSIR-National Chemical Laboratory, Pune, India

Correspondence: Dr SG Dastager, NCIM Resource Center, CSIR-National Chemical Laboratory, Pashan Road, Pune, Maharastra 411008, India.

E-mail: sg.dastager@ncl.res.insyedmicro@gmail.com

or Professor Wen-Jun Li, Key Laboratory of Microbial Diversity in Southwest China, Ministry of Education and Laboratory for Conservation and Utilization of Bio-resources, Yunnan Institute of Microbiology, Yunnan University, Kunming, Yunnan 650091, PR China.

E-mail: wjil@ynu.edu.cn
}

Received 18 September 2014; revised 20 January 2015; accepted 16 February 2015; published online 18 March 2015 
that was white to light pink appeared on all the media tested. Substrate mycelium was branched extensively and the colors on various media were pink to reddish pink-brownish yellows. No soluble pigments were observed on any media (Table 1). The aerial hyphae produced long and spiral spore chains, which had a spiral structure bearing 10 spores (Figure 1). Unless specified

Table 1 Cultural characteristics of the strains of DRQ-2 ${ }^{\top}$ on different growth media

\begin{tabular}{llll}
\hline Medium & Aerial mycelium & Substrate mycelium & $\begin{array}{l}\text { Soluble } \\
\text { pigment }\end{array}$ \\
\hline ISP2 & Light Pink & Reddish pink & None \\
ISP3 & Light Pink & Reddish pink & None \\
ISP4 & Pink & Dark pink & None \\
ISP5 (glycerol- & White & Reddish yellow & None \\
asparagine agar) & & & None \\
ISP6 & Pinkish white & Pink & None \\
Nutrient Agar & White & Light red & None \\
Czapeks Dox agar & White & Pinkish orange & None \\
Glucose-asparagine agar & White & Light brownish yellow & None \\
Starch casein agar & Light pink & Dark pink & .
\end{tabular}

otherwise, the following morphological and physiological characteristics were investigated using ISP2 as the basal medium. The temperature and $\mathrm{pH}$ for the growth were determined at $4,10,20,30,37,45,50$ and $55^{\circ} \mathrm{C}$ and at an initial $\mathrm{pH} 4.0-12.0$ (at intervals of $\mathrm{pH} 1.0$ unit), respectively. $\mathrm{NaCl}$ tolerance for growth was tested on ISP 4 medium supplemented with $1-9 \%$ (w/v) $\mathrm{NaCl}$. Gram staining, oxidase activity was tested by spreading cell pellets on oxidase test paper (Hi-Media, Mumbai, India) and catalase activity was tested by using a $3 \% \mathrm{H}_{2} \mathrm{O}_{2}$ solution, degradation ability and utilization of carbohydrates were determined using previously described methods of Lee and Lee. ${ }^{14}$ Other physiological and biochemical properties were tested using the API- $50 \mathrm{CH}$, API-20E and API-ZYM kits (bioMérieux, Marcy l'Etoile, France) according to the recommendations of the manufacturer. Colonial morphology and pigmentation of the cells were observed and recorded after an incubation of 14 days at $45^{\circ} \mathrm{C}$. Cell morphology and motility were observed by using phase contrast and scanning electron microscopy. For scanning electron microscopy examination, $1-\mathrm{ml}$ samples were fixed overnight at $4{ }^{\circ} \mathrm{C}$ by adding formaldehyde to a final concentration of $7 \%$. Nine milliliter phosphate-buffered saline $(130 \mathrm{~mm} \mathrm{NaCl}$, $10 \mathrm{~mm}$ sodium phosphate, $\mathrm{pH} 7.0 \pm 0.2$ ) was added to the samples, which were then filtered through 0.2- $\mu \mathrm{m}$ Millipore filters (Merck, Bengaluru, India) and washed with phosphate-buffered saline. The filters were then serially dehydrated in 25, 50, 70 and 100\% ethanol solutions (three times for $10 \mathrm{~min}$ at each stage), critical-point dried, mounted on scanning electron microscope stubs, sputter coated with gold and viewed on Philips XL30 (FEI Company, Hillsboro, OR, USA); ESEM-TMP.

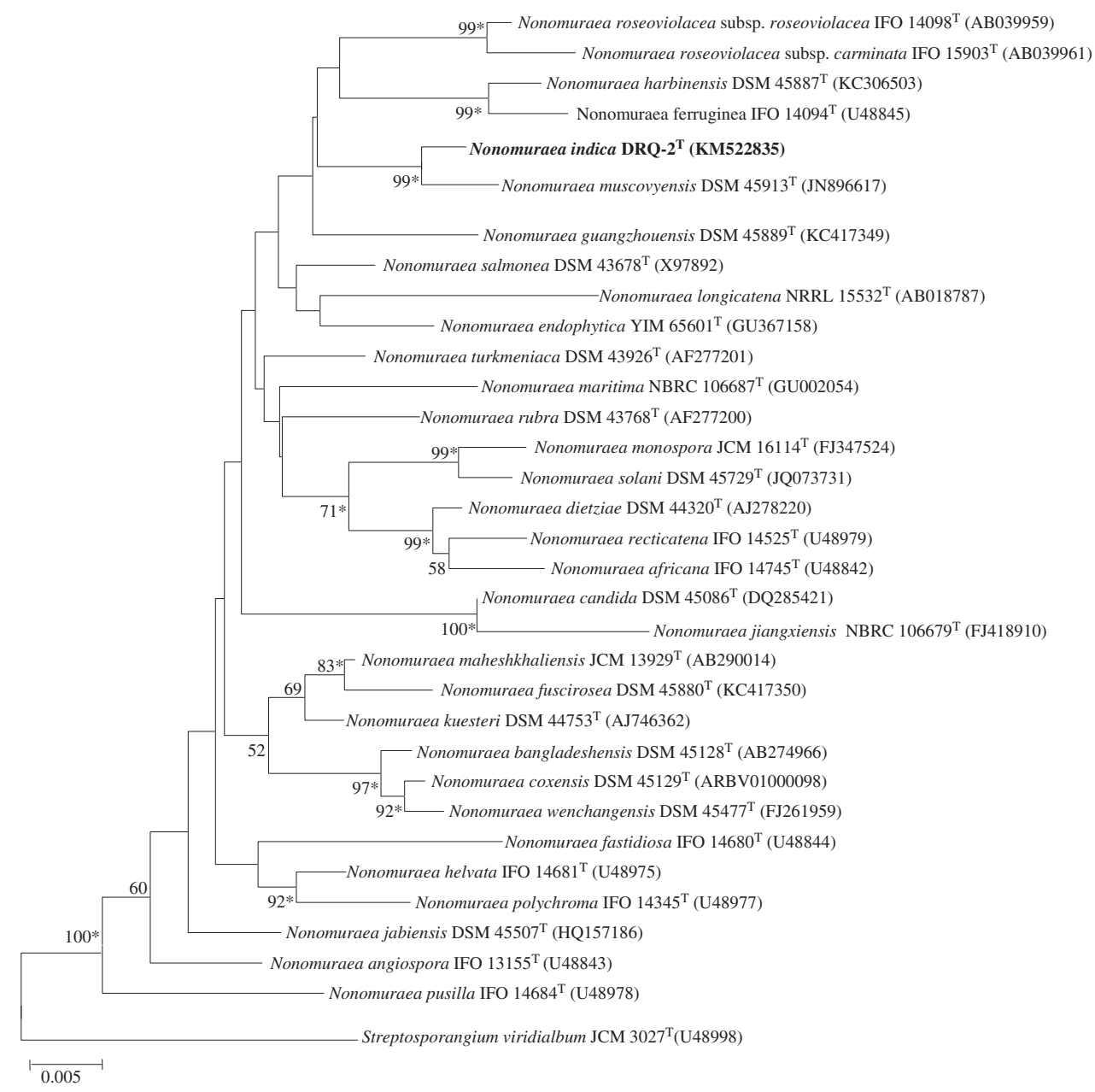

Figure 1 Neighbour-joining tree based on nearly complete $16 \mathrm{~S}$ rRNA gene sequences showing the relationship between the strain DRQ-2 ${ }^{\top}$ and all the validly published species of the genus Nonomuraea. Asterisks indicate phyletic lines that were also recovered using the minimum- and maximum-likelihood algorithm. Bootstrap values were expressed as a percentage of 1000 replications. Only bootstrap values of $>50 \%$ are shown. Scale bar, 0.005 substitutions per site. 
16S rRNA gene sequencing and phylogenetic analyses

Extraction of genomic DNA and PCR amplification of 16S rRNA gene were done as described by Li et al. ${ }^{15}$ Multiple alignments with sequences of the most closely related Nonomuraea and the calculations of levels of sequence similarity were carried out using http://eztaxon-e.ezbiocloud.net of Kim et al. ${ }^{16}$ Phylogenetic analyses were performed using three tree-making algorithms that were the neighbour-joining, ${ }^{17}$ maximum-likelihood ${ }^{18}$ and maximum-parsimony ${ }^{19}$ methods. A phylogenetic tree was constructed using the neighbor-joining method of Saitou and $\mathrm{Nei}^{17}$ from Knuc values ${ }^{20}$ using MEGA version 6.0. ${ }^{21}$ The topology of the phylogenetic tree was evaluated by the bootstrap resampling method of Felsenstein ${ }^{18}$ with 1000 replicates. The genomic DNA of strain DRQ- $2^{\mathrm{T}}$ for the determination of $\mathrm{G}+\mathrm{C}$ content was prepared according to the method of Marmur. ${ }^{22}$ The G+C content of the DNA was determined by reverse-phase HPLC of nucleosides according to Mesbah et al. ${ }^{23}$ NA was hydrolyzed and the resultant nucleotides were analyzed by reversed phase HPLC. ${ }^{23}$ DNA-DNA hybridization was carried out based on the principles and equations described by De Ley et al. ${ }^{24}$ under the consideration of the modifications carried out by Huss et al. ${ }^{25}$ and the optimized fluorimetric procedure by Loveland-Curtze et al. ${ }^{26}$ was evaluated by using a Step One Plus Real-Time PCR system (Applied Biosystems, Foster City, CA, USA) fitted with 96-well thermal cycling blocks. DNA dissolved in the $2 \times$ SSC is used for the analysis in three independent samples. The reassociations were carried out at an optimum renaturation temperature of $65^{\circ} \mathrm{C} . .^{27,28}$

\section{Chemotaxonomy}

Chemotaxonomic characteristics were investigated as described by Lee and Lee, ${ }^{14}$ with cell biomass obtained from the culture grown in yeast malt glucose broth $(0.4 \%$ yeast extract, $1.0 \%$ malt extract and $0.4 \%$ glucose, $\mathrm{pH} 7.2)$ for 5 days at $45^{\circ} \mathrm{C}$ for the isomer of diaminopimelic acid in cell wall, ${ }^{29}$ respiratory quinones, ${ }^{30,31}$ polar lipids ${ }^{32}$ and DNA G+C content. ${ }^{23}$ Strain DRQ-2 ${ }^{\mathrm{T}}$ was grown on tryptone soy broth agar for 5 days at $45^{\circ} \mathrm{C}$ for fatty acid analysis. The cellular fatty acid methyl esters were prepared and analyzed according to the standard protocol of the Microbial Identification System (version 6; MIDI, Newark, DE, USA).

\section{Nucleotide sequence accession number}

The 16S rRNA gene sequence of strain DRQ- $2^{\mathrm{T}}$ determined in this study has been deposited in GenBank under the accession number KM522835.

\section{RESULTS AND DISCUSSION}

An almost complete $16 \mathrm{~S}$ rRNA gene sequence (1426 nt) of strain DRQ- $2^{\mathrm{T}}$ determined in this study was compared with those of the
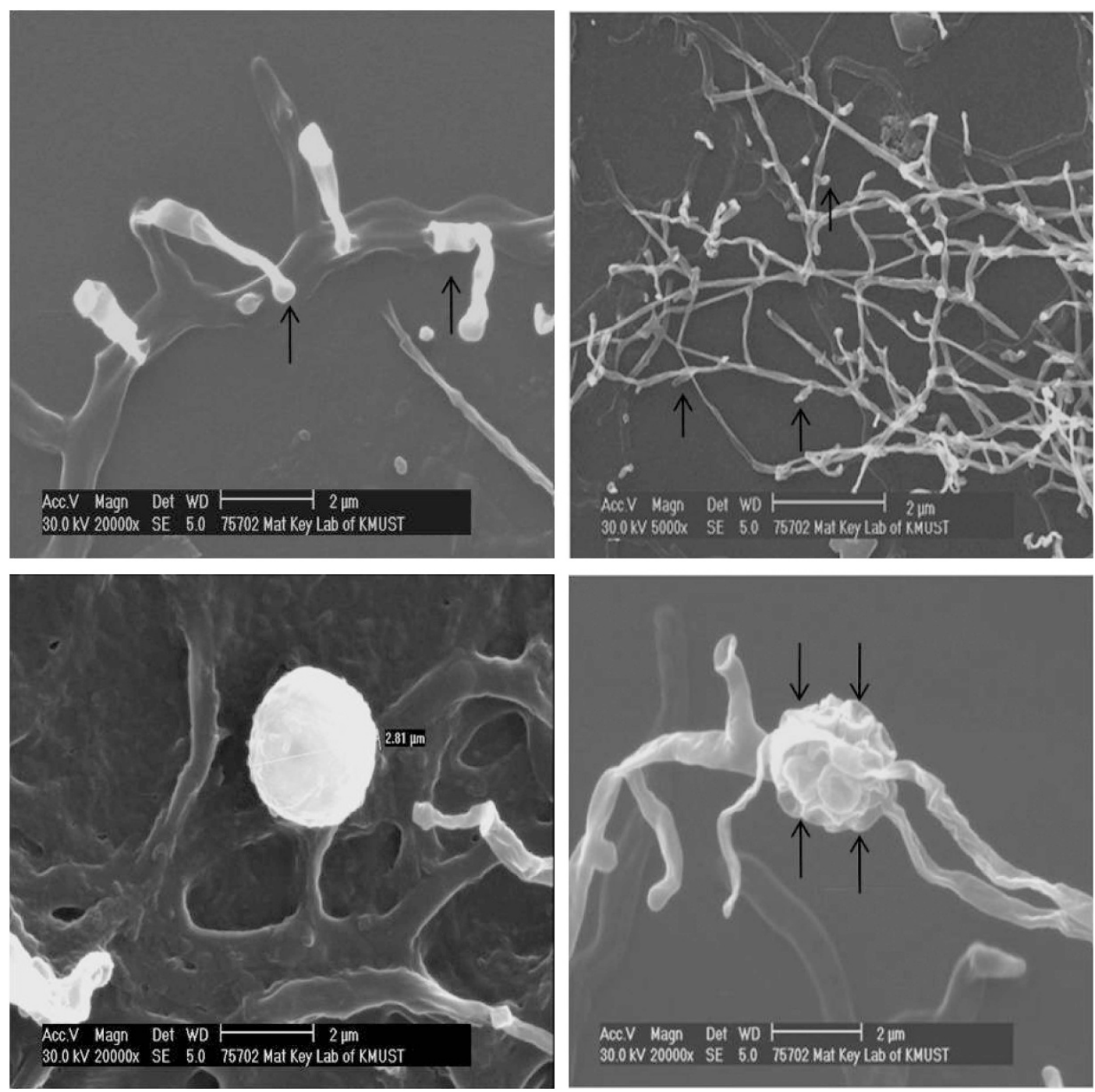

Figure 2 Scanning electron micrograph of $N$.onomuraea indica sp. nov., DRQ- $2^{\top}$ grown on ISP 4 at $28^{\circ} \mathrm{C}$ for 7 days. Scale bar, $2 \mu \mathrm{m}$. Arrow marks indicates the mycelium structure and spores arrangement. 
representative species of the genus Nonomuraea. The results of $16 \mathrm{~S}$ rRNA gene sequence comparison clearly demonstrated that strain DRQ-2 ${ }^{\mathrm{T}}$ is a member of the genus Nonomuraea. Strain DRQ-2 ${ }^{\mathrm{T}}$ was showing highest sequence similarity to $N$. muscovyensis DSM $45913^{\mathrm{T}}$ (99.1\%), N. salmonea DSM 43678 ${ }^{\mathrm{T}}(98.2 \%)$ and N. maheshkhaliensis JCM $13929^{\mathrm{T}}(98.0 \%)$ with 12,25 and $28 \mathrm{nt}$ differences, respectively. In the phylogenetic tree based on the neighbour-joining algorithm, strain DRQ-2 ${ }^{\mathrm{T}}$ formed a separate clade with N. muscovyensis DSM $45913^{\mathrm{T}}$ in the same branch with a higher bootstrap value of $99 \%$ (Figure 1). Topologies of phylogenetic trees built using the maximum-likelihood and maximum-parsimony algorithms were similar to those of the tree constructed by the neighbour-joining analysis (Supplementary Figures S1 and S2). The 16S rRNA gene sequence similarities between strain DRQ-2 ${ }^{\mathrm{T}}$ and its closest neighbor, N. muscovyensis DSM $45913^{\mathrm{T}}$ (99.1\%), N. salmonea DSM $43678^{\mathrm{T}}$ (98.2\%) and N. maheshkhaliensis JCM $13929^{\mathrm{T}}$ (98.0\%) were further subjected for DNA-DNA hybridization. The DNA-DNA hybridization have a key role in microbial species discrimination in cases when 16S rRNA gene sequence, depending on the investigated taxonomic group, the threshold value has been increased to between 98.2 and $99.0 \%$ and it appears reasonable as recommended by Stackebrandt and Ebers ${ }^{33}$ and Meier-Kolthoff et al., ${ }^{34}$ we have included two strains with above $99 \%$ similarity to two type strains with $\leqslant$ recommended threshold value. The $\mathrm{G}+\mathrm{C}$ content of the DNA was $72.5 \mathrm{~mol} \%$. The determined DNA-DNA relatedness value between strain DRQ- ${ }^{\mathrm{T}}$ and its closest neighbor, N. muscovyensis DSM 45913 ${ }^{\mathrm{T}}$, N. salmonea DSM $43678^{\mathrm{T}}$ and N. maheshkhaliensis JCM $13929^{\mathrm{T}}$ were $39.5 \pm 3.2 \%, 48 \pm 2.0 \%$ and $41.7 \pm 2.5 \%$, respectively (with s.d. in triplicate). DNA hybridization results indicated that, values of hybridizations were well below the
$70 \%$ cutoff point for the recognition of novel genomic species, ${ }^{35}$ thus suggesting that the strain DRQ- $2^{\mathrm{T}}$ should be considered as a new species of the genus Nonomuraea.

Cells of strain DRQ-2 ${ }^{\mathrm{T}}$ were aerobic, Gram-stain positive, nonmotile $(0.6-1.0 \mu \mathrm{m}$ in diameter) that were present singly, in pairs or in clusters (Figure 2). Matured spore was not observed. Colonies of the cells were light pinkish, circular, convex with entire margins and reached $0.1-0.2 \mathrm{~mm}$ in diameter after an incubation for 5 days. Data for the other physiological and biochemical characteristics, and the species description are given in Table 2. Strain DRQ- $2^{\mathrm{T}}$ contained meso diaminopimelic acid and also showed the presence of galactose, glucose, mannose, ribose and madurose as whole-cell sugars. The predominant menaquinone was $\mathrm{MK}-9\left(\mathrm{H}_{4}\right)$. The polar lipids comprised of diphosphatidylglycerol, phosphatidylmono methyl ethanolamine (PME), phosphatidylethanolamine (PE), hydroxy-PME (OH-PME), hydroxy phosphatidylethanolamine (OH-PEE), phosphatidylglycerol (PG), ninhydrin-positive phosphoglycolipid and unknown phospholipid were detected as phospholipids (Supplementary Figure S3). The DNA G+C content of strain DRQ-2 ${ }^{\mathrm{T}}$ was $72.5 \mathrm{~mol} \%$. The fatty acid profile of strain DRQ-2 ${ }^{\mathrm{T}}$ was characterized by large amounts of saturated and unsaturated fatty acids. The major fatty acids were $\mathrm{i}-\mathrm{C}_{16: 0}(37.8), \mathrm{C}_{17: 0} 10$-methyl (16.8), iso- $\mathrm{C}_{16: 0} 2 \mathrm{OH}(11.2)$, ai- $\mathrm{C}_{17: 0}(9.4)$ and $\mathrm{i}-\mathrm{C}_{15: 0}(6.1)$ and the minor fatty acids $(<5 \%)$ were $\mathrm{C}_{17: 0}(4.2), \mathrm{i}-\mathrm{C}_{17: 0} 2 \mathrm{OH}(2.1)$, iso- $\mathrm{C}_{17: 0} 2 \mathrm{OH}$ (2.1), i- $\mathrm{C}_{16: 1}(1.7)$, i- $\mathrm{C}_{17: 0}(1.5), \mathrm{i}-\mathrm{C}_{14: 0}(1.1)$ and $\mathrm{C}_{15: 0}$ (1.0). Some of the fatty acids were absent compared with its nearest phylogenetic neighbors like, $\mathrm{C}_{14: 0}$, summed feature 4 , whereas some fatty acids are higher in percentage compared with its neighbor. Detailed comparision of the fatty acids has been given in Supplementary Material in

Table 2 Comparison of the phenotypic properties of DRQ-2 ${ }^{\top}$ with those species of the genus Nonomuraea with validly published names

\begin{tabular}{|c|c|c|c|c|}
\hline Characteristic & $D R Q-2^{T}$ & N. muscovyensis DSM 45913' & N. salmonea DSM $43678^{T}$ & N. maheshkhaliensis DSM 45163 \\
\hline \multicolumn{5}{|l|}{ Growth on ISP3 medium } \\
\hline Aerial mycelium & Light pink & Yellowish brown & Pinkish white & White \\
\hline Substrate mycelium & Reddish pink & Brownish orange & Moderate red & Light wheat \\
\hline Soluble pigments & None & None & None & None \\
\hline \multicolumn{5}{|l|}{ Biochemical Tests } \\
\hline Aesculin hydrolysis & + & + & + & + \\
\hline Nitrate Reductase & + & + & + & + \\
\hline \multicolumn{5}{|l|}{ Degradation of } \\
\hline Casein & + & - & - & - \\
\hline Gelatin & + & - & - & - \\
\hline Hypoxanthine & + & - & & \\
\hline Starch & + & - & - & \\
\hline Tyrosine & - & - & + & + \\
\hline Xanthine & + & - & - & - \\
\hline \multicolumn{5}{|l|}{ Utilization of } \\
\hline L-Arabinose & + & - & - & + \\
\hline D-Fructose & + & - & - & + \\
\hline myo-Inositol & - & - & - & - \\
\hline D-Mannose & - & - & - & + \\
\hline L-Rhamnose & + & + & + & + \\
\hline Sucrose & + & + & + & + \\
\hline D-Xylose & + & + & - & + \\
\hline Gelatinase & + & + & - & - \\
\hline Urease & - & - & - & - \\
\hline
\end{tabular}

All data were obtained in this study. Symbols: +, positive; -, negative. 
Supplementary Table S1. Besides the genotypic evidence above, the strain DRQ- $2^{\mathrm{T}}$ could also be distinguished from their related species by phenotypic characteristics (Table 2). It is evident from the phenotypic, chemotaxonomic and phylogenetic data that strain DRQ-2 ${ }^{\mathrm{T}}$ should be given a novel species status in the genus Nonomuraea, for which we propose the name $N$. indica sp. nov.

\section{Description of Nonomuraea indica sp. nov.}

Nonomuraea indica (in'di.ca. L. fem. adj. indica pertaining to India, Indian.).

Cells are aerobic, Gram positive, oxidase negative, catalase positive, nonmotile $(0.6-1.0 \mu \mathrm{m}$ in diameter), that are present singly, in pairs or as cluster. Colonies are light pink, circular, convex with entire margins and reached $0.1-0.2 \mathrm{~mm}$ in diameter after an incubation of 14 days. Growth is observed at $\mathrm{pH} 6.0-12.0$ (optimum at $\mathrm{pH} 9.0$ ), $5-55^{\circ} \mathrm{C}$ (optimum at $45^{\circ} \mathrm{C}$ ) and $0-10 \%(\mathrm{w} / \mathrm{v}) \mathrm{NaCl}$ (optimum at $4 \% \mathrm{NaCl}$ ). The cells were positive for amylase, asparaginase, cellulase, gelatinase, glutaminase and protease; and negative for citrate utilization, and urease hydrolysis. $\mathrm{H}_{2} \mathrm{~S}$ production was not observed. D-glucose, Lrhamnose, D-sucrose, D-melibiose and L-arabinose are utilized as sole carbon and energy source but D-mannitol, inositol, D-sorbitol and amygdalin are not. Data for the other physiological and biochemical properties are given in Table 1. Meso-diaminopimelic acid is the diagnostic diamino acid in cell-wall peptidoglycan. The polar lipids comprised of diphosphatidylglycerol, PME, phosphatidylethanolamine (PE), hydroxy-PME (OH-PME), hydroxy phosphatidylethanolamine (OH-PEE), phosphatidylglycerol (PG), ninhydrin-positive phosphoglycolipid and unknown phospholipid were detected as phospholipids. The predominant menaquinones were MK-7, MK-9, MK-9 $\left(\mathrm{H}_{2}\right)$, MK-9 $\left(\mathrm{H}_{4}\right)$ and MK-9 $\left(\mathrm{H}_{6}\right)$ in the ratio of 13.1:4.6: 12.6: 49.3:10.7 (\%). The major fatty acids are $\mathrm{i}-\mathrm{C}_{16: 0}, \mathrm{i}-\mathrm{C}_{16: 0} 2 \mathrm{OH}, \mathrm{C}_{17: 0}$ 10-methyl and $\mathrm{i}-\mathrm{C}_{15: 0}$. The type strain DRQ-2 ${ }^{\mathrm{T}}\left(\mathrm{NCIM} 5480^{\mathrm{T}}=\mathrm{CCTCC}\right.$ AA $209050^{\mathrm{T}}$ ) was isolated as DRQ-2 ${ }^{\mathrm{T}}$ from lime-stone open pit of the Gulbarga region of Karnataka province, India. The DNA G+C content of the type strain is $72.5 \mathrm{~mol} \%$.

\section{ACKNOWLEDGEMENTS}

This work was supported by the National Basic Research Program of China (no. 2010CB833801) and the National Natural Science Foundation of China (no. 31070007) and the International Cooperation Research Program of Yunnan Province (no. 2009AC017). W-JL was supported by the Program for the New Century Excellent Talents in University. W-JL was also supported by the Guangdong Province Higher Vocational Colleges \& Schools Pearl River Scholar Funded Scheme (2014), SGD was supported by the Council of Scientific and Industrial Research (CSIR) and CSIR-NCL, India. The GenBank accession number of the $16 \mathrm{~S}$ rRNA gene sequence of Nonomuraea indica $\mathrm{DRQ}^{\mathrm{T}}$-is KM522835.

1 Zhang, Z., Wang, Y. \& Ruan, J. Reclassification of Thermomonospora and Microtetraspora. Int. J. Syst. Bacteriol. 48, 411-422 (1998).

2 Chiba, S., Suzuki, M. \& Ando, K. Taxonomic re-evaluation of 'Nocardiopsis' sp. K-252 ${ }^{\top}$ ( = NRRL 15532 T): a proposal to transfer this strain to the genus Nonomuraea as Nonomuraea longicatena sp. nov. Int. J. Syst. Bacteriol. 49, 1623-1630 (1999).

3 Quintana, E., Maldonado, L. \& Goodfellow, M. Nonomuraea terrinata sp. nov., a novel soil actinomycete. Antonie Van Leeuwenhoek 84, 1-6 (2003).
4 Zhang, X. et al. Nonomuraea fuscirosea sp. nov., an actinomycete isolated from the rhizosphere soil of rehmannia (Rehmannia glutinosa Libosch). Int. J. Syst. Evol. Microbiol. 64, 1102-1107 (2014).

5 Camas, M. et al. Nonomuraea jabiensis sp. nov., isolated from arid soil. Int. J. Syst. Evol. Microbiol. 63, 212-218 (2013)

6 Sripreechasak, P. et al. Nonomuraea thailandensis sp. nov. isolated from Thai soil. J. Antibiot. 66, 79-84 (2013).

7 Cao, Y. R., Jin, R. X., Jiang, Y., He, W. X. \& Jiang, C. L. Nonomuraea soli sp. nov., an actinomycete isolated from soil. Int. J. Syst. Evol. Microbiol. 62, 1587-1591 (2012).

8 Stackebrandt, E., Wink, J., Steiner, U. \& Kroppenstedt, R. M. Nonomuraea dietzii sp. nov. Int. J. Syst. Evol. Microbiol. 51, 1437-1441 (2001).

9 Kämpfer, P., Kroppenstedt, R. M. \& Grün-Wollny, I. Nonomuraea kuesteri sp. nov. Int. J. Syst. Evol. Microbiol. 55, 847-851 (2005).

10 Dastager, S. G. et al. . Streptomyces gulbargensis sp. nov., isolated from soil in Karnataka, India. Antonie Van Leeuwenhoek 91, 99-104 (2007)

11 Dastager, S. G. Streptomyces tritolerans sp. nov., a novel actinomycete isolated from soil in Karnataka, India. Antonie. Van. Leeuwenhoek 92, 391-397 (2007)

12 Dastager, S. G., Kim, C.-J., Lee, J.-C., Agasar, D., Park, D.-J. \& Li, W.-J. Streptomyces deccanensis sp. nov., an alkaliphilic species isolated from soil. Int. J. Syst. Evol. Microbiol. 58, 1089-1093 (2008).

13 Shirling, E. B. \& Gottlieb, D. Methods for characterisation of Streptomyces species. Int. J. Syst. Bacteriol. 16, 313-340 (1966).

14 Lee, D. W. \& Lee, S. D. Aeromicrobium ponti sp. nov., isolated from seawater. Int. J. Syst. Evol. Microbiol. 58, 987-991 (2008).

$15 \mathrm{Li}$, W. J. et al. Georgenia ruanii sp. nov., a novel actinobacterium isolated from forest soil in Yunnan (China) and emended description of the genus Georgenia. Int. J. Syst. Evol. Microbiol. 57, 1424-1428 (2007)

$16 \mathrm{Kim}, \mathrm{O} . \mathrm{K}$. et al. Introducing EzTaxon-e: a prokaryotic 16S rRNA gene sequence database with phylotypes that represent uncultured species. Int. J. Syst. Evol. Microbiol. 62, 716-721 (2012)

17 Saitou, N. \& Nei, M. The neighbor-joining method: a new method for reconstructing phylogenetic trees. Mol. Biol. Evol. 4, 406-425 (1987).

18 Felsenstein, J. Confidence limits on phylogenies: an approach using the bootstrap. Evolution 39, 783-791 (1985).

19 Fitch, W. M. Towards defining the course of evolution: Minimum change for a specific tree topology. Syst. Zoo. 20, 406-416 (1971).

20 Kimura, M. A simple method for estimating evolutionary rates of base substitutions through comparative studies of nucleotide sequences. J. Mol. Evol. 16, 111-120 (1980)

21 Tamura, K., Stecher, G., Peterson, D., Filipski, A. \& Kumar, S. MEGA 6: Molecular Evolutionary Genetics Analysis 6.0. Mol. Biol. Evol. 30, 2725-2729 (2013).

22 Marmur, J. A procedure for the isolation of deoxyribonucleic acid from microorganisms. J. Mol. Biol. 3, 208-218 (1961).

23 Mesbah, M., Premachandran, U. \& Whitman, W. B. Precise measurement of the G+C content of deoxyribonucleic acid by high performance liquid chromatography. Int. J. Syst. Bacteriol. 39, 159-167 (1989).

24 De Ley, J., Cattoir, H. \& Reynaerts, A. The quantitative measurement of DNA hybridization from renaturation rates. Eur. J. Biochem. 12, 133-142 (1970).

25 Huss, V. A. R., Festl, H. \& Schleifer, K. H. Studies on the spectrophotometric determination of DNA hybridization from renaturation rates. Syst. Appl. Microbiol. 4, 184-192 (1983)

26 Loveland-Curtze, J., Miteva, V. I. \& Brenchley, J. E. Evaluation of a new fluorimetric DNA-DNA hybridization method. Can. J. Microbiol. 57, 250-255 (2011).

27 Gillis, M., De Ley, J. \& De Cleene, M. The determination of molecular weight of bacterial genome DNA from renaturation rates. Eur. J. Biochem. 12, 143-153 (1970).

28 Marmur, J. \& Doty, P. Determination of the base composition of deoxyribonucleic acid from its thermal denaturation temperature. J. Mol. Biol. 5, 109-118 (1962).

29 Staneck, J. L. \& Roberts, G. D. Simplified approach to identification of aerobic actinomycetes by thin-layer chromatography. Appl. Microbiol. 28, 226-231 (1974).

30 Collins, M. D., Faulkner, M. \& Keddie, R. M. Menaquinone composition of some spore forming actinomycetes. Syst. Appl. Microbiol. 5, 20-29 (1984).

31 Kroppenstedt, R. M. In: Chemical Methods in Bacterial Systematics. (eds Goodfellow, M. \& Minnikin, D. E.) 173-199 (Academic Press: London, UK, 1985).

32 Minnikin, D. E., Pirouz, T. \& Goodfellow, M. Polar lipid composition in the classification of some Actinomadura species. Int. J. Syst. Bacteriol. 27 118-121 (1977)

33 Stackebrandt, E. \& Ebers, J. Taxonomic parameters revisited: tarnished gold standards. Microbiol. Today 33, 152-155 (2006).

34 Meier-Kolthoff, P. J., Alexander, F. A., Klenk, H. P. \& Göker, M. Genome sequencebased species delimitation with confidence intervals and improved distance functions. BMC Bioinformatics 14, 60 (2013).

35 Wayne, L. G. et al. Report of the ad hoc committee on reconciliation of approaches to bacterial systematics. Int. J. Syst. Bacteriol. 37, 463-464 (1987)

Supplementary Information accompanies the paper on The Journal of Antibiotics website (http://www.nature.com/ja) 